УДК 61:004.45

\title{
ПРО ПІДХІД ДО ОРГАНІЗАЦІЇ ІНФОРМАЦІЙНОГО СЕРЕДОВИЩА ПІДРОЗДІЛУ МЕДИЧНОГО ВНЗ У СОЦІАЛЬНИХ МЕРЕЖАХ
}

\author{
А. В. Семенець, В. Ю. Ковалок \\ ДВНЗ "Тернопільський державний медичний університет \\ імені І. Я. Горбачевского МОЗ України" \\ ON THE APPROACH OF ORGANIZATION OF THE SOCIAL \\ NETWORK INFORMATION ENVIRONMENT OF THE MEDICAL \\ UNIVERSITY DEPARTMENT
}

\author{
A. V. Semenets, V. Yu. Kovalok \\ SHEI "Ternopil State Medical University by I. Ya. Horbachevsky ofMPH of Ukraine"
}

\begin{abstract}
Застосування соціальних мереж як засобу освіти має ряд переваг для користувачів інформаційного середовища медичного ВНЗ. У роботі показано сучасний стан та перспективи застосування соціальних мереж у галузі медичної освіти України. Представлено методику використання можливостей соціальних мереж у Тернопільському державному медичному університеті ім. І. Я. Горбачевського та наведено статистику їх застосування протягом 2014 року. Запропоновано підхід до формування інформаційного представництва підрозділу медичного ВНЗ у соціальних мережах на основі досвіду кафедри медичної інформатики ТДМУ Висвітлено питання автоматизації задач щодо розміщення публікацій у соціальних мережах. Проаналізовано ефективність вказаного підходу.
\end{abstract}

The social networks usage as the educational tool have brought some benefits for the users of the medical universities information environments. The current state and perspectives of the application of the social networks to the Ukrainian medical education area are shown.The methodology of the social networks application in the Ternopil State Medical University named I. Ya. Horbachevsky is presented. An approach of the information representation of the department of the medical university in the social networks based on the experience of TSMU Medical Informatics Department is proposed.The solution for the automated reposting process in the social networks is offered.The detailed instruction for the development of the information environment of the department of the medical university in the social networks is also presented. An assessment of this approach is displayed.

Вступ. Розвиток освіти на основі принципів безперервності, рівного доступу, особистісної спрямованості формує сучасну модель освіти - відкриту освіту - що покликана реалізувати принцип навчання протягом всього життя. Метою відкритої освіти є підготовка студентів до повноцінної й ефективної участі у громадській та професійній діяльності в умовах інформаційного суспільства.

Динамічний розвиток інформаційних і комп'ютерних технологій відкриває нові можливості для спілкування і взаємодії, дає потенціал для підвищення ефективності навчального простору організації соціально значимих навчальних і методичних проектів. В даний час розширюється використання можливостей корпоративних соціальних мереж, а також соціальних мереж вільного доступу у формуванні єдиного інформаційного середовища вузу. Застосування соціально-освітніх мереж створює переваги для корис-

(C) А. В. Семенець, В. Ю. Ковалок тувачів інформаційного середовища медичного ВНЗ: зрозумілий інтерфейс, зручне спілкування, участь у спільнотах з різних навчальних і наукових інтересів; мультимедійність комунікативного простору, зручні форми роботи з науково-освітнім контентом, можливість особистісно-орієнтованого навчання, контролю успішності в режимі "он-лайн"; суміщення індивідуальної та групової форм навчальної роботи, колективна оцінка процесів і результатів роботи, спостереження за розвитком кожного студента; оперативне оповіщення про всі зміни в особистому інформаційному просторі; перенесення освітнього процесу у віртуальний простір, що важливо при обмежених площах навчальних аудиторій; мобільність доступу до інструментів соціальної мережі [1,2].

Основна частина. Галузь медичної освіти України повинна забезпечити підготовку фахівців, здатних використовувати можливості всіх сучасних інформаційних і комп'ютерних технологій, включно з засобами соціальних мереж, для організації ефективної ко- 
мунікації та обміну даними між всіма представниками галузі охорони здоров'я з метою підвищення якості діагностики надання медичної допомоги. В роботах $[3,4]$ А. В. Семенцем розглянуто концептуальні напрямки впровадження сучасних інформаційних технологій у галузі медичної освіти.

1. Перспективи застосування соціальних мереж у галузі медичної освіти України

Моніторингові організації, такі, як Gemius Ukraine (www.gemius.com.ua), Інтернет Асоціація України (http://www.inau.org.ua), StatCounter (http:// gs.statcounter.com) та ряд інших, протягом останнього десятиліття фіксують стійкі тенденцій щодо цільової аудиторії та використання соціальних мереж в Україні, зокрема [5-7]:
- стабільне щорічне зростання аудиторії користувачів на 5-15\%;

- частка користувачів віком до 35 років становить більше $55 \%$;

- від 35 до 60 \% користувачів мають вищу або незакінчену вищу освіту.

Діаграми (рис. 1,2) відображають зростання відносного та абсолютного рівня популярності окремих соціальних мереж в Україні станом на другу половину 2014 р. заданими моніторингових організацій Gemius Ukraine та StatCounter[5, 7].

Аналіз аудиторії користувачів соціальних мереж за віком та рівнем освіти (рис. 3,4 ) показує значну перспективність використання даних інтернет-ресурсів у галузі медичної освіти.

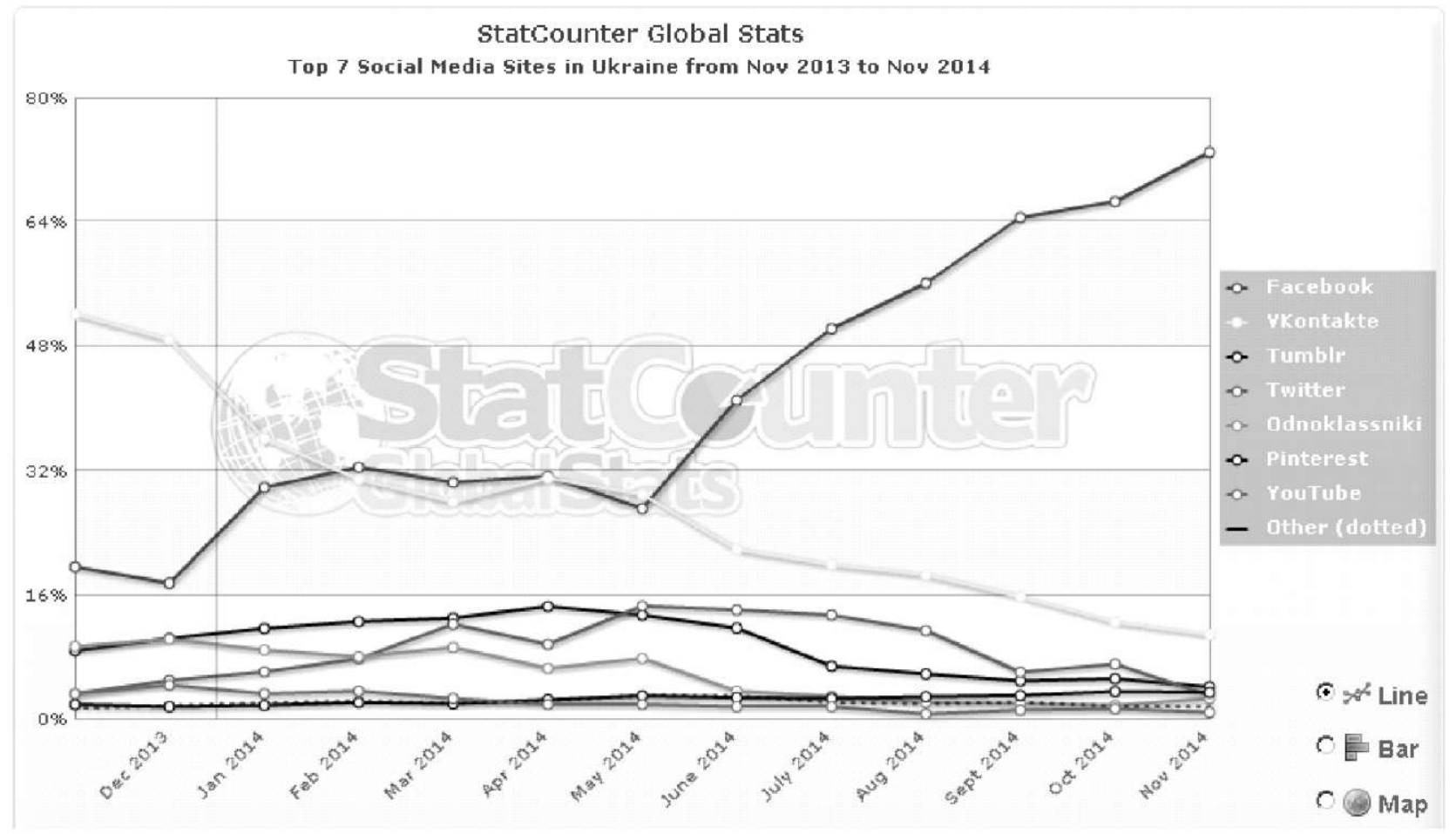

Рис. 1. Популярність соціальних мереж в Україні за даними StatCounter (станом на листопад 2014 р.).

Таким чином, є очевидним, що соціальна мережа - одна з найпопулярніших, доступних, звичних для користувачів, зручних для отримання та обміну знаннями в освітніх цілях, перспективних інтернеттехнологій. Основні напрямки застосування даних інтернет-сервісів в єдиному інформаційному середовищі вузу становлять $[1,2,8,9]$ :

- залучення учасників освітнього процесу та взаємодія з ними в соціальних мережах у вільному доступі;
- створення віртуального освітнього середовища, в тому числі організація безперервної освіти в середовищі e-learning в корпоративних соціально-освітніх мережах;

- організація професійних співтовариств - віртуальних робочих груп студентів, викладачів, аспірантів, магістрантів за проектами (в розрізі профілів професійної підготовки, напрямів науковихдосліджень та інших видів спільної роботи) як у вільному режимі, так і в корпоративних науково-освітніх соціальних мережах. 


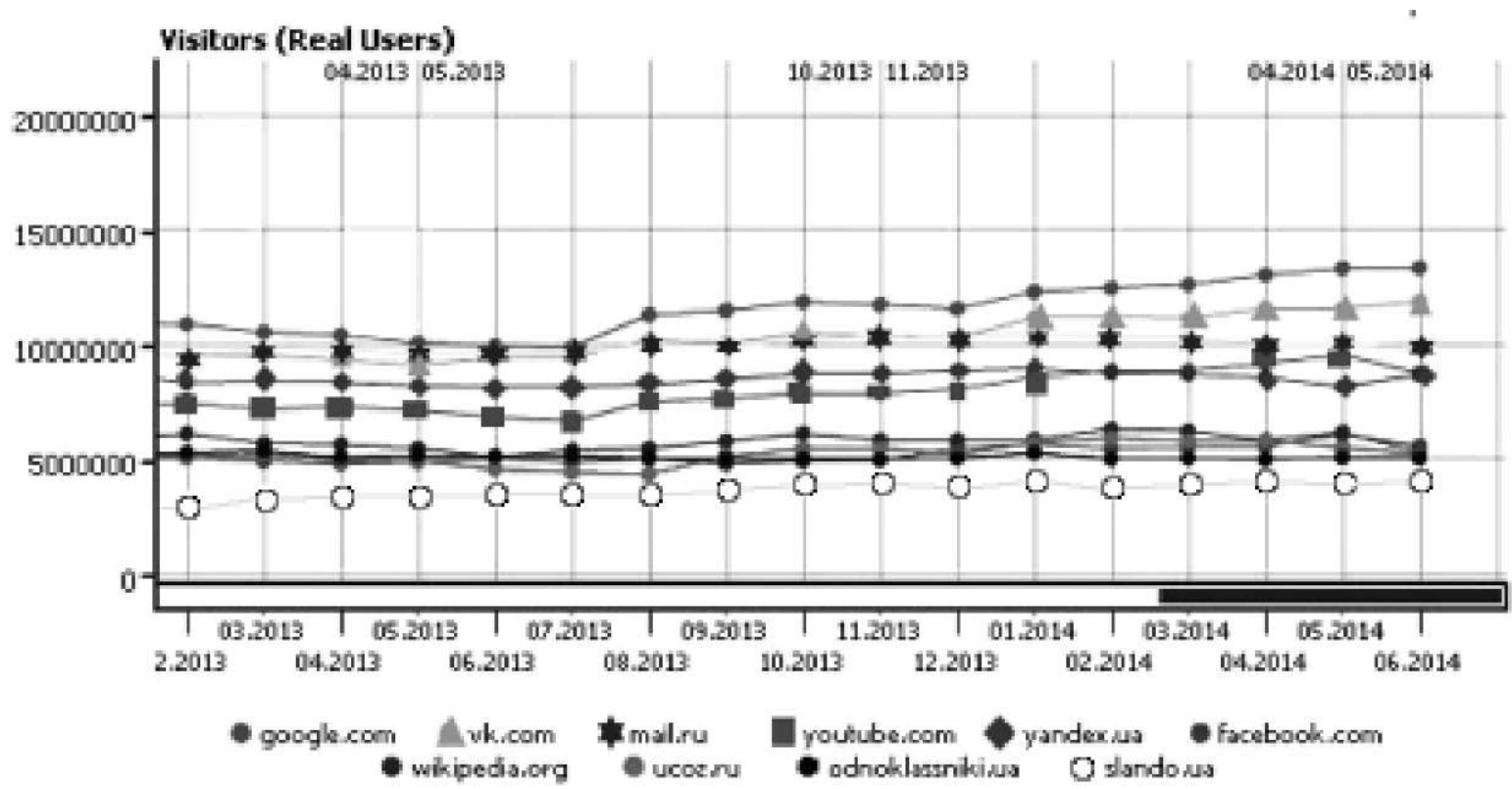

Рис. 2. Найбільш популярні сайти (включно з соціальними мережами) в Україні за даними Gemius Ukraine (станом на липень 2014 р.).

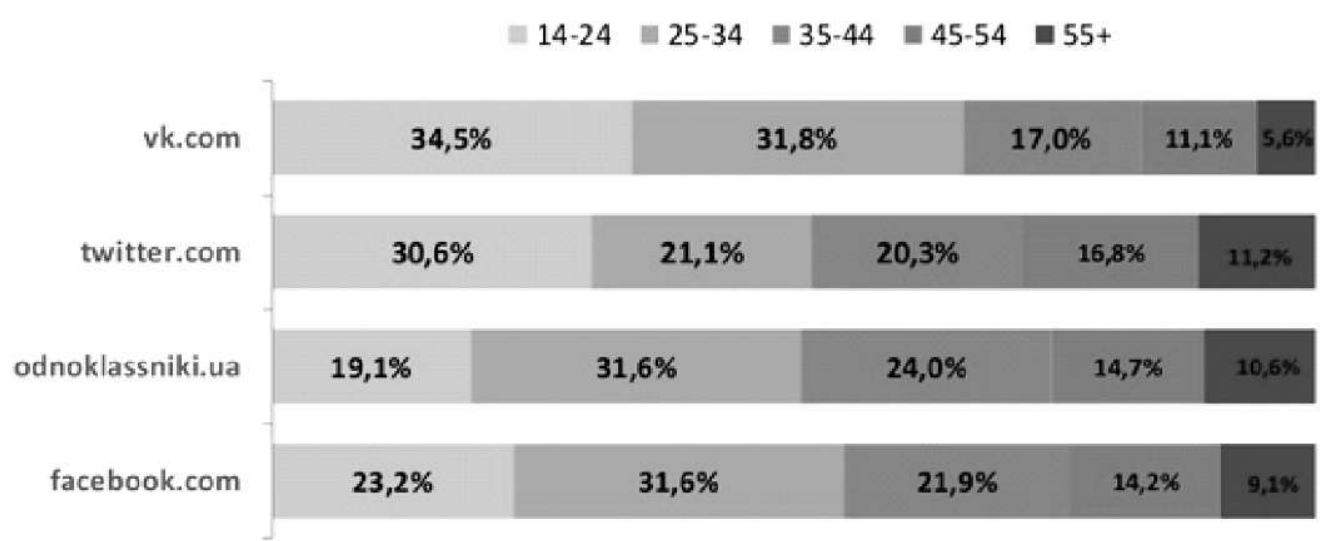

Рис. 3. Розподіл користувачів соціальних мереж за віком за даними Gemius Ukraine (червень 2014 р.).

Шачальное, незаконченное среднее $=$ Среднее = Среднее специальное = Неполное высшее

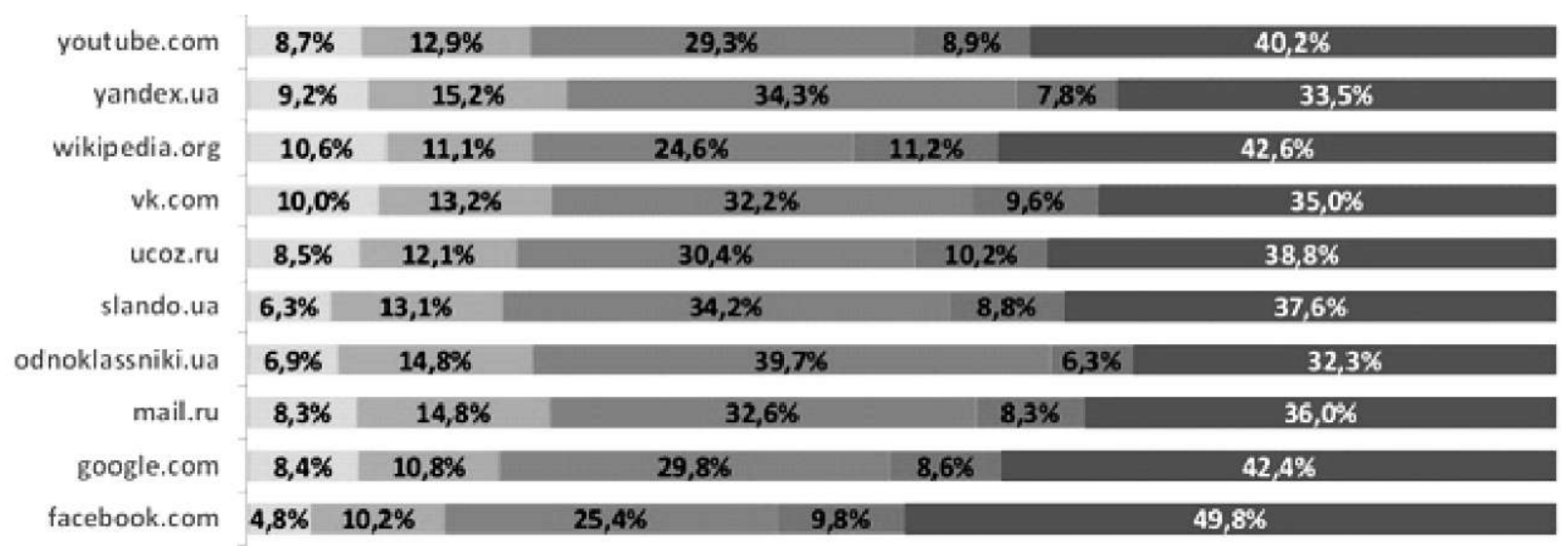

Рис. 4. Розподіл користувачів 10 найбільш відвідуваних сайтів за рівнем освіти за даними Gemius Ukraine (червень 2014 р.). 
У роботах $[8,9]$ показано, що завдяки своїй свободі та відкритості соціальні мережі допомагають вузу залучати потенційних споживачів освітніх послуг, а також зсередини бачити життя своїх студентів, будучи, тим самим, джерелом нових ідей. Абітурієнти на тривалому етапі активної оцінки вузів користуються рекомендаціями знайомих, відвідують сайти різних вузів, форуми, блоги, соціальні мережі. Після зарахування студенти включаються в інтерактивне обговорення, діляться враженнями про вуз в Інтернеті, користуючись соціальними мережами, дуже швидко формуючи репутацію вузу.

2. Методика використання соиіальних мереж уТДМУ

2.1. Прочес формування інформаційного представництва ТДМУ в соичіальних мережах

Використання соціальних мереж для широкого висвітлення питань функціонування університету було запропоновано авторами у 2012 році. Практично реалізація даної ініціативи розпочалася в 2013 одночасно $з$ початком використання хмарного сервісу Google Apps for Education [10]. Соціальна мережа Google + (https://plus.google.com/) є одним з компонентів вказаного хмарного сервісу. У власності корпорації Google також перебуває сервіс публікації відеозаписів Youtube (https://www.youtube.com).

У березні 2014 р. В. Ю. Ковалок виконав комплекс заходів щодо створення та первинного налаштування домашньої сторінки ТДМУ для використання в якості інформаційного представництва навчального закладу в таких соціальних мережах (рис. 5):

- Google + - https://plus.google.com/ 1151254647703 51075121/posts;

- YouTube - https://www.youtube.com/channel/ UCCwOL-NkpaJAsikOzjvngoQ;

- Facebook - https://www.facebook.com/tdmu.official;

- Twitter - https://twitter.com/TDMU_UA.

Після проведення відповідного навчання права на публікацію новин на вказаних сторінках були передані прес-службі університету.

У листопаді 2014 р. авторами забезпечено отримання адміністративного доступу до спеціальної сторінки ТДМУ як навчального закладу (https:// wwwlinkedin.com/edu/school?id=17672) в соціальній мережі для професійних контактів Linkedln (рис. 6). Цей спеціалізований сервіс було започатковано Linkedln в серпні 2013 р. з метою надання абітурієнтам можливості оцінки рейтингу освітнього закладу та перспектив майбутнього кар'єрного росту випускника [11].

Слід зазначити що В. Ю. Ковалок уник типових помилок недосвідчених адміністраторів, котрі реєструють представництво організації у соціальних мережах як фізичну особу (рис. 7). Усі вищевказані сторінки ТДМУ зареєстровано та налаштовано згідно 3 вимогами відповідних соціальних мереж до сторінок, що представляють організацію як юридичну особу.

2.2. Статистика використання сочіальних мереж у ТДМУ

Станом на кінець грудня 2014 р. авторами зібрано статистичні дані щодо використання потенціалу соціальних мереж прес-службою ТДМУ та іншими уповноваженими користувачами університету (табл. 1, рис. 8,9). Аналіз вказаних даних показує такі основні напрямки використання соціальних мережу ТДМУ:

- ознайомлення аудиторії користувачів з різноманітними подіями, які відбуваються в університеті: організаційного, навчально-наукового, соціально-побутового, мистецько-культурного, національно-патріотичного характеру. При цьому переважно застосовуються Facebook та Google + ;

- офіційна інформація щодо результатів проведення наукових конференцій, з' їздів, семінарів, тренінгів. Протягом 2014 року для 3 наукових конференцій було застосовано пряму трансляцію (стрім) на YouTubeканал ТДМУ.

Однак автори вимушені зазначити ряд суттєвих недоліків щодо використання існуючих сторінок ТДМУ в соціальних мережах:

- не відображається планування майбутніх заходів (наявний лише 1 анонс наукового семінару);

- дуже мала кількість навчального контенту чи посилань на інші освітні ресурси;

- слабо ілюструються результати науково-дослідної роботи професорсько-викладацького складу університету;

- надзвичайно низька активність використання сервіcy YouTube (опубліковано всього 5 відеозаписів зарік);

- застарілий основний сайт університету (www.tdmu.edu.ua) не має можливостей залучати нових користувачів до сторінок ТДМУ в соціальних мережах;

- відсутність публікацій на сторінці ТДМУ в соціальній мережі для професійних контактів Linkedln, що має негативний вплив на інтернет-рейтинг університету. 

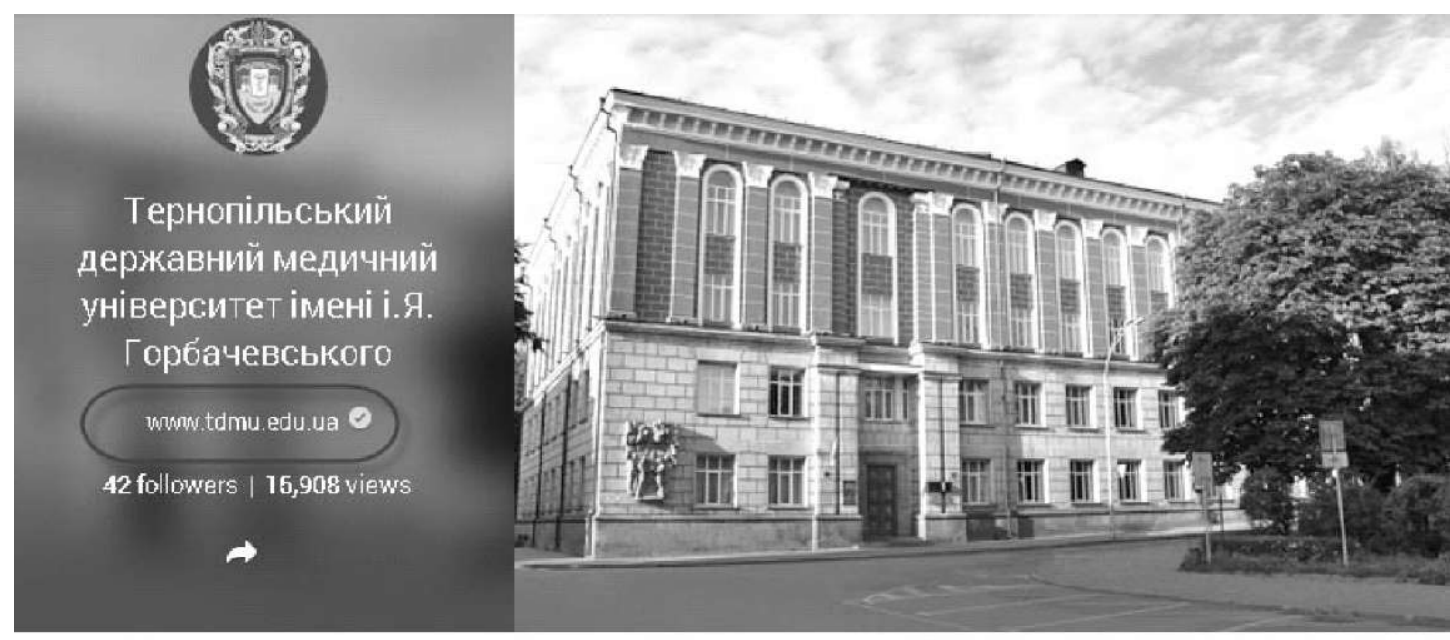

About Posts Photos youTube Reviews

People

In their cireles

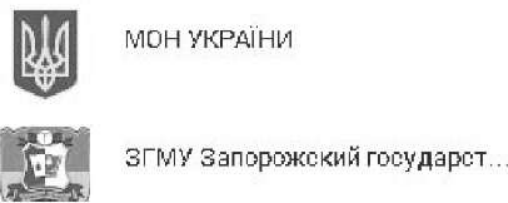

\section{Story}

24 people Tagline

Тернопільський державний медичний університет імені І. Я. Горбачевського

\section{Introduction}

офіційна сторінка державного вищого навчального

закладу Тернопільський державний медичний

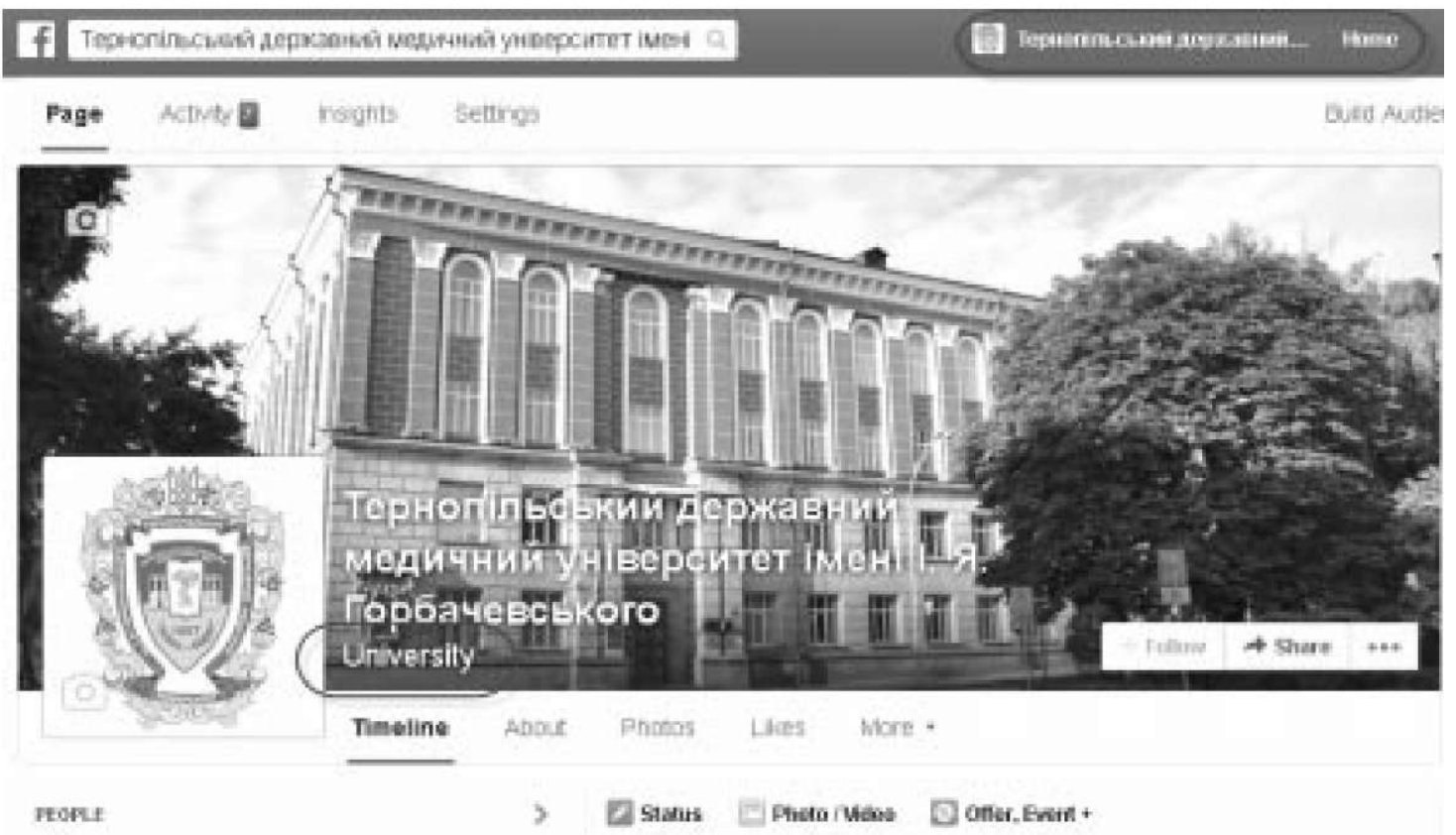

376 ines

in: whac have you oesen up to?

Pис. 5. Сторінки ТДМУ в соціальних мережах Google + (a) та Facebook (б). 


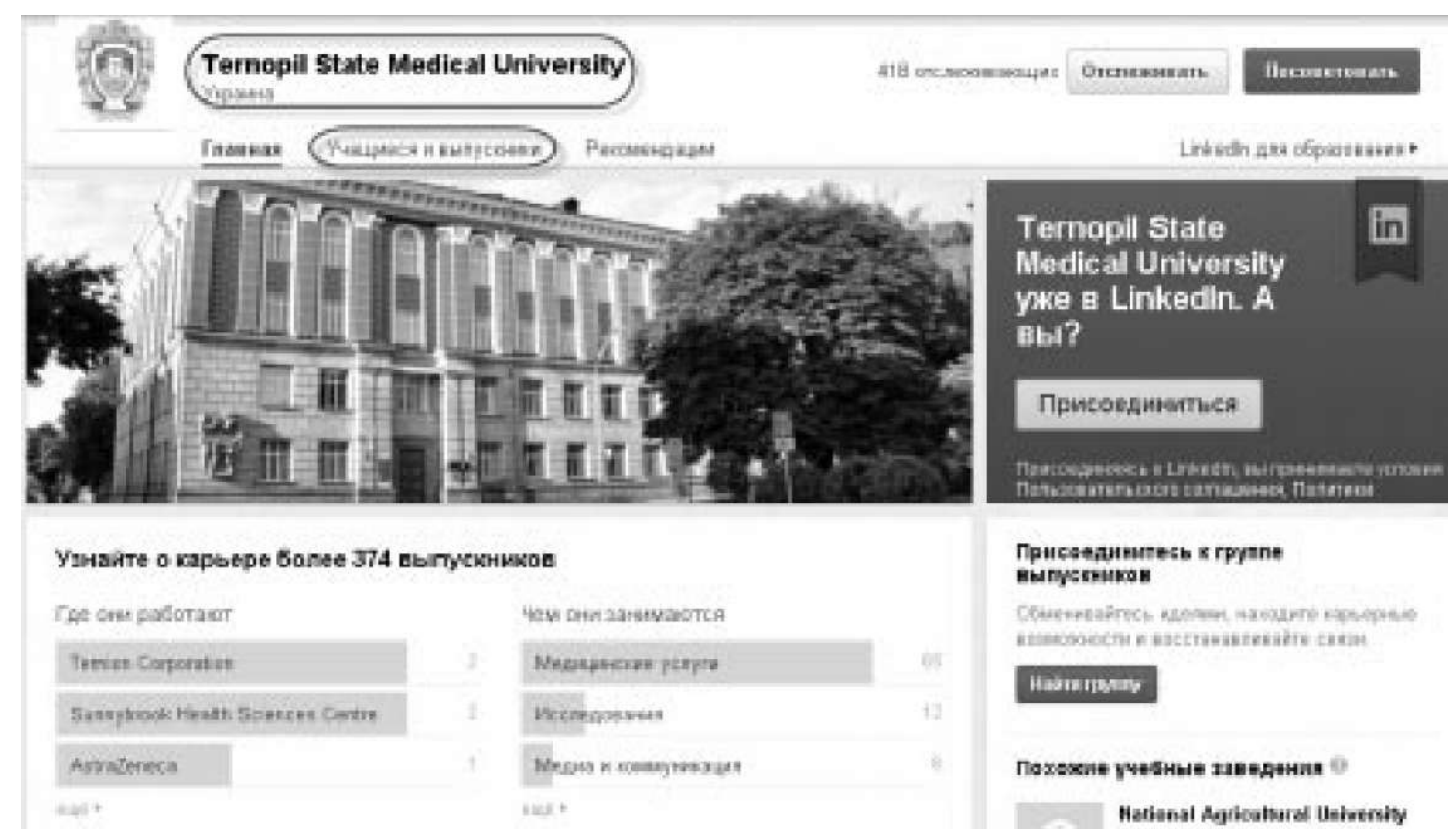

Рис. 6. Сторінка ТДМУ як навчального закладу в соціальній мережі для професійних контактів Linkedln.

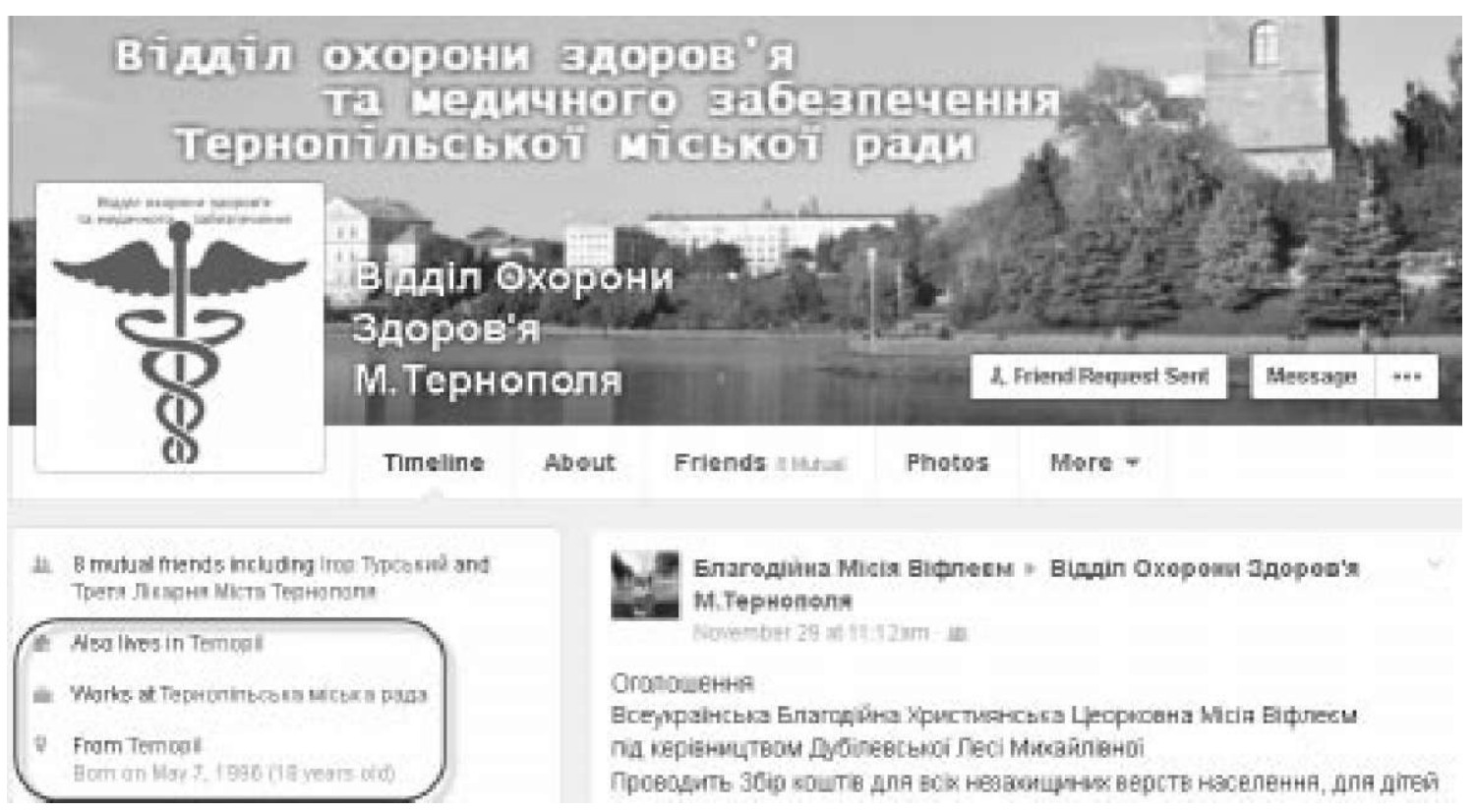

Рис. 7. Типовий приклад неправильного представлення юридичної особи (організації) в соціальних мережах.

Таблиця 1. Зведені дані щодо використання соціальних мереж у ТДМУ

\begin{tabular}{|l|c|c|c|}
\hline Назва соціальної мережі & $\begin{array}{c}\text { Повідомлень } \\
\text { (всього/за місяць) }\end{array}$ & $\begin{array}{c}\text { Переглядів } \\
\text { (всього/за місяць) }\end{array}$ & Підписників \\
\hline Google + & $135 / 14$ & 16,7 тис. $/ 1,7$ тис. & 42 \\
\hline Facebook & $285 / 30$ & 26,4 тис. $/ 2,8$ тис. & 376 \\
\hline Twitter & $298 / 31$ & - & 33 \\
\hline YouTube & 5 & 1,7 тис. $/ 0,18$ тис. & 33 \\
\hline Linkedln & 0 & - & 415 \\
\hline
\end{tabular}




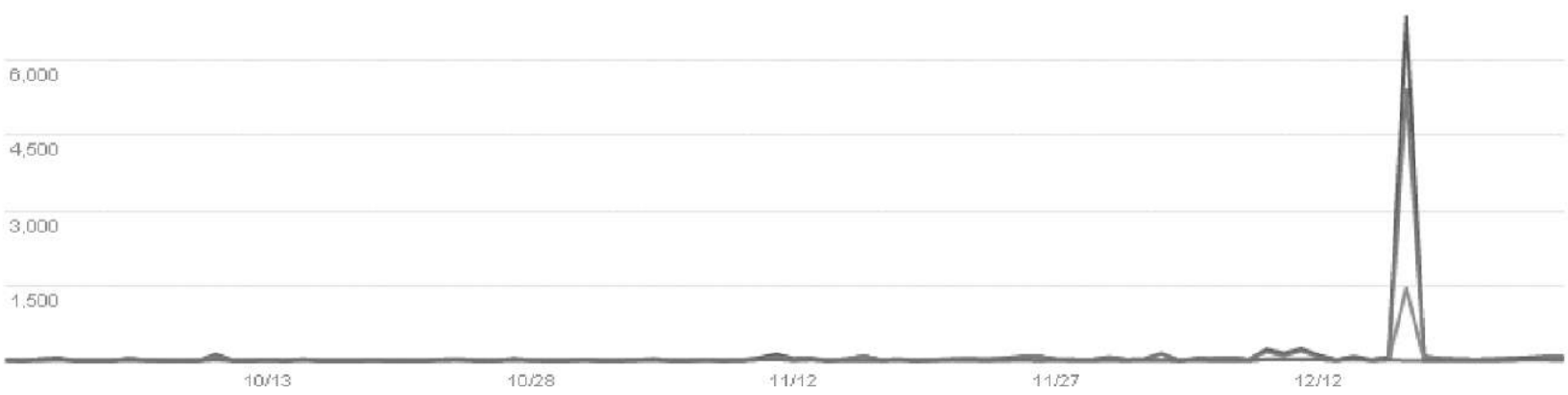

Рис. 8. Діаграма відвідуваності сторінки ТДМУ в соціальній мережі Google + протягом 4 кварталу 2014 року.

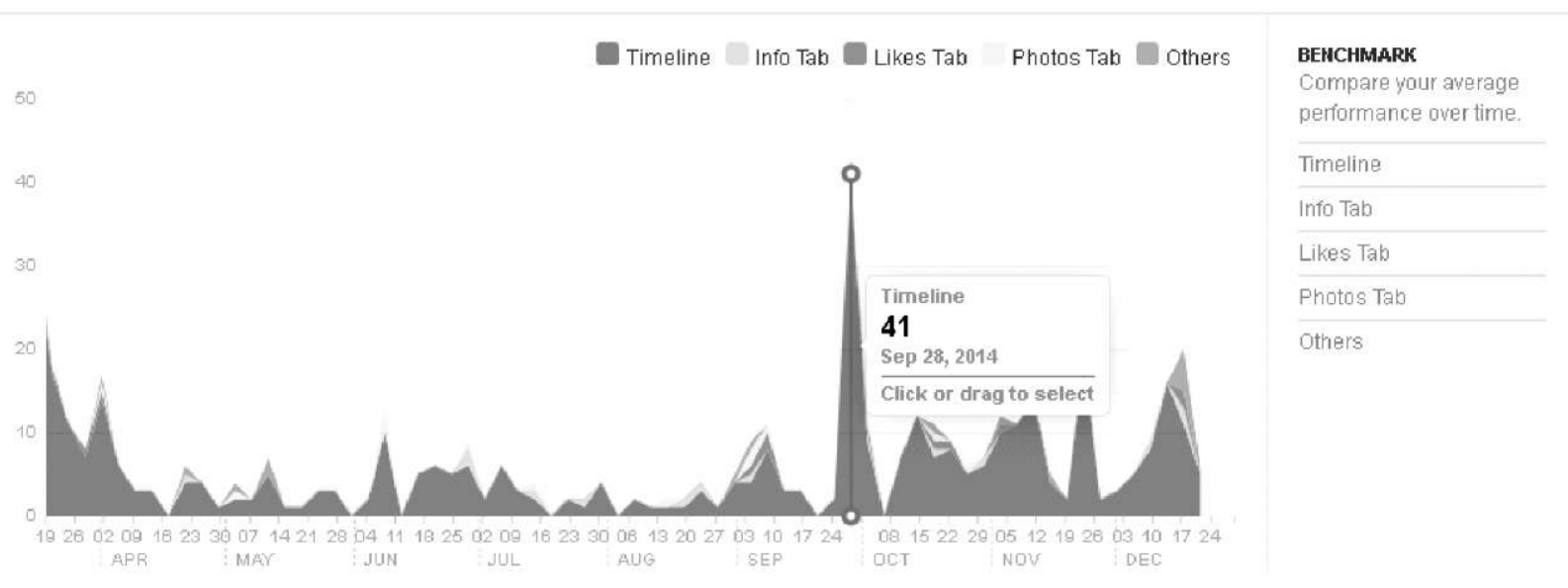

Рис. 9. Діаграма відвідуваності сторінки ТДМУ в соціальніймережіРасеьоокпротягом2014 року (з моменту створення).

3. Формування автоматизованого інформаційного представництва кафедри медичного ВНЗ у соиіальних мережах

3.1. Реєстрачія сторінок кафедри медичної інформатики в соиіальних мережах з елементами автоматизації розміщення повідомлень

На думку А. В. Семенеця, один $з$ шляхів подолання більшої частини вказаних недоліків - формування інформаційних представництв окремих кафедр (підрозділів) медичного ВНЗ у соціальних мережах. Таким чином, є можливим суттєво підвищити як кількість контенту, що генерується у ВНЗ, так і його якість. У випадку кафедри медичної інформатики засоби соціальних мереж забезпечують:

- інформування студентів та колег щодо заходів, які плануються до проведення на кафедрі;
- формування додаткового каналу для комунікації зі студентами;

- представлення результатів наукової роботи кафедри для широкого кола зацікавлених осіб;

- висвітлення окремих аспектів наукової діяльності викладачів кафедри;

- популяризація останніх досягнень в галузі медичної інформатики та інформаційних технологій у фармації.

Формування інформаційного представництва кафедри медичної інформатики ТДМУ в соціальних мережах було здійснено А. В. Семенецем в кінці листопада - на початку грудня 2014 р. При цьому було враховано аналогічний досвід для сторінок університету. Зокрема, одним 3 найактуальніших завдань постала проблема максимальної автоматизації розміщення матеріалів. Це питання є актуальним для 
невеликого професорсько-викладацького колективу кафедри, на відміну від університету з повноцінною прес-службою. Нижче представлено типовий алгоритм формування інформаційного представництва кафедри медичного ВН3 у соціальних сервісах Google:

1. Вихідною умовою для початку налаштування $€$ використання в медичному ВН3 сервісу GoogleApps for Education [10].

2. Адміністратор сервісу GoogleApps for Education створює облікові записи в домені для викладачів кафедри.

3. Викладачі кафедри активують власні облікові записи. Для цього достатньо авторизуватись у поштовому сервісі Gmail.

4. Викладачі кафедри створюють персональні сторінки в соціальній мережі Google + та на сервері відеохостингу YouTube. Для цього достатньо вибрати відповідний сервіс у меню керування власним обліковим записом Google Apps та підтвердити створення сторінки.

5. Завідувач кафедри призначає уповноваженого викладача на роль менеджера інформаційних сторінок у соціальних мережах.

6. Менеджер на власній сторінці ініціює створення додаткової сторінки Google My Business (https:// www.google.com/business/), яка і буде інформаційним представництвом кафедри (рис. 10).

7. Менеджер надає необхідні права викладачам кафедри для забезпечення можливості публікації повідомлень на сторінці кафедри.

8. Для отримання публічного доступу сторінка повинна бути верифікована шляхом вказання посилання на існуючий веб-сайт кафедри чи університету (за участі адміністратора домену Google Apps for Education).

9. Просування сторінки кафедри в соціальній мережі здійснюється шляхом залучення підписників (followers) на основі механізму Кіл Google (http:// www.google.com/+/learnmore/circles/).

10. Отримання 10 підписників дає право менеджеру створити на сервері відеохостингу YouTube канал для даної сторінки (рис. 11) з правом вивантаження файлів відеозаписів чи онлайнової трансляції засобами Google Hangouts (https://plus.google.com/hangouts/).

На цьому базовий етап формування інформаційного представництва кафедри медичного ВНЗ у соціальних сервісах Google Apps for Education закінчено. Наступний крок включає залучення окрім Google + аудиторії інших соціальних мереж та автоматизацію розміщення матеріалів.
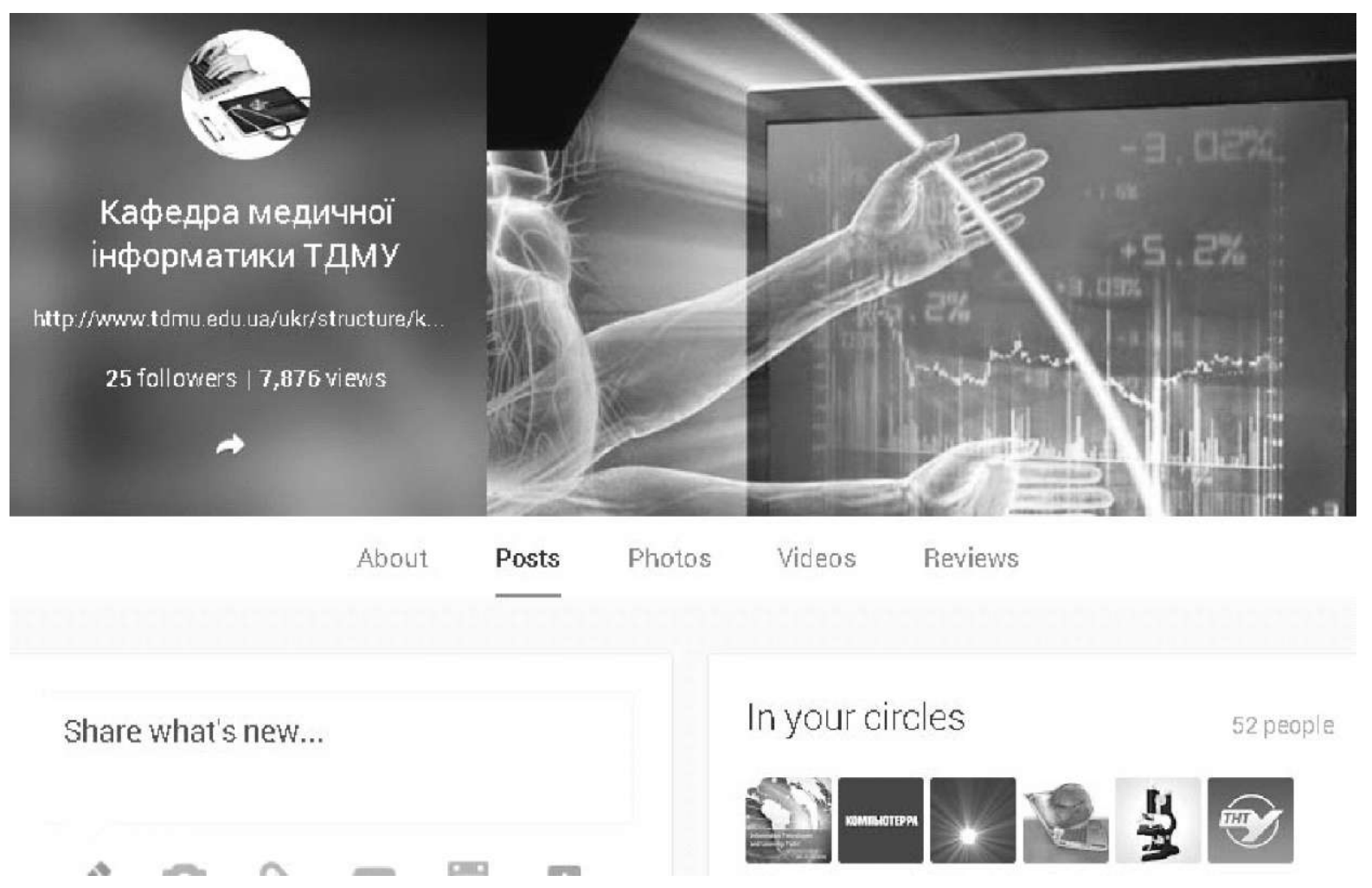

Рис. 10. Сторінка кафедри медичної інформатики ТДМУ в соціальній мережі Google +. 

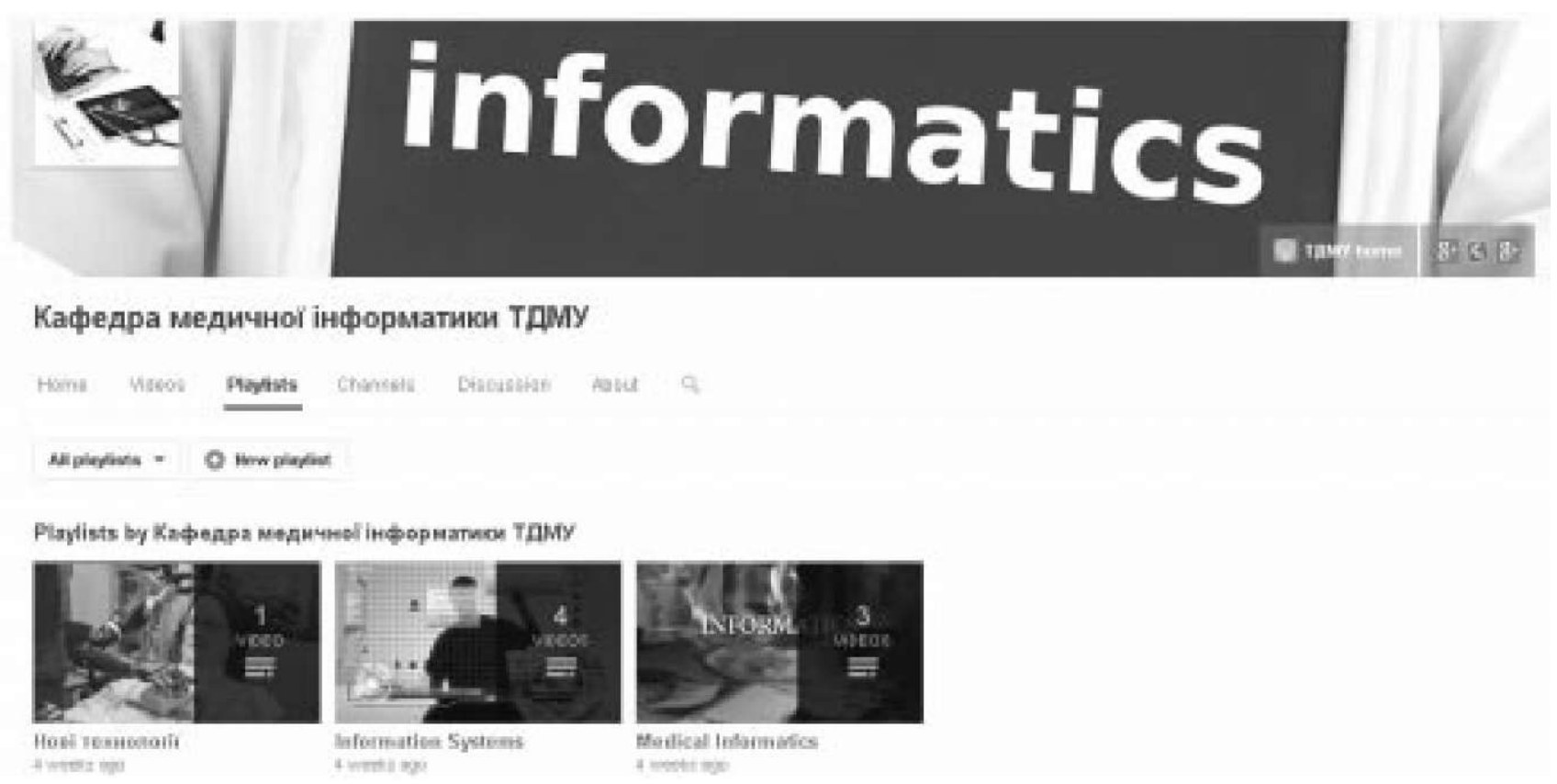

Рис. 11. Сторінка кафедри медичної інформатики ТДМУ на сервері відеохостингу YouTube.

Враховуючи досвід ТДМУ, а також динаміку розвитку соціальних мереж протягом 2014 р. (див. п. 1),

А. В. Семенцем було вирішено формувати інформаційне представництво кафедри медичної інформатики в таких соціальних мережах, як Facebook, Linkedln та Twitter. Основною вимогою було автоматичне розміщення нових повідомлень (репост) 3 сторінки кафедри в соціальній мережі Google +. Нижче представлено типовий алгоритм розширення інформаційного представництва кафедри медичного ВНЗ у соціальних мережах з елементами автоматизації:

1. Менеджер реєструє персональний обліковий запис у соціальній мережі Facebook та активує іiі (верифікація на основі адреси електронної пошти).

2. Використовуючи персональний обліковий запис, менеджер створює Facebook-сторінку (Page) кафедри як організації освітнього спрямування (рис. 12). Для підвищення рейтингу сторінки слід ретельно поставитися до налаштування її параметрів та здійснити пошук облікових записів колег, співробітників та пов'язаних організацій.

3. Менеджер реєструє персональний обліковий запис у соціальній мережі Linkedln та активує її (верифікація на основі повідомлення електронної пошти). Також є можливість здійснити перший вхід з використанням авторизації за допомогою існуючого персонального облікового запису в соціальній мережі Facebook. Специфіка даної мережі вимагає обов'язкового наповнення профілю персональною інформацією.
4. Використовуючи рекомендації [12], менеджер створює сторінку кафедри як організації (рис. 13). При цьому також необхідно здійснити верифікацію на основі адреси електронної пошти (корпоративної).

5. Реєстрація облікового запису організації в соціальній мережі Twitter повністю аналогічна до процедури реєстрації персонального облікового запису (рис. 14). При цьому також необхідно здійснити верифікацію на основі адреси електронної пошти.

На даному етапі менеджер кафедри має доступ до всіх створених інформаційних сторінок у соціальних мережах. Однак публікація повідомлень у кожній 3 них окремо є занадто трудомісткою справою. Логічним бачиться пошук способу автоматизації поширення повідомлень відразу в кількох соціальних мережах.

Соціальна мережа Facebook містить вбудовані засоби для публікації інформації про активність на сторінці з використанням облікового запису в соціальній мережі Twitter [13]. Параметри налаштування показано на рисунку 15. Аналогічні налаштування авторами було виконано і для сторінки ТДМУ в соціальній мережі Facebook.

Складнішою є ситуація з автоматизацією пересилання публікацій між Google + та іншими соціальними мережами. Корпорація Google не пропонує вбудованих засобів для цього. Однак існують рішення у вигляді спеціалізованих сервісів, що дозволяють реалізувати необхідну функціональність [14]. А. В. Семенцем застосовано сервіс Magenta River (https:// magentariver.com) для автоматичного розміщення 


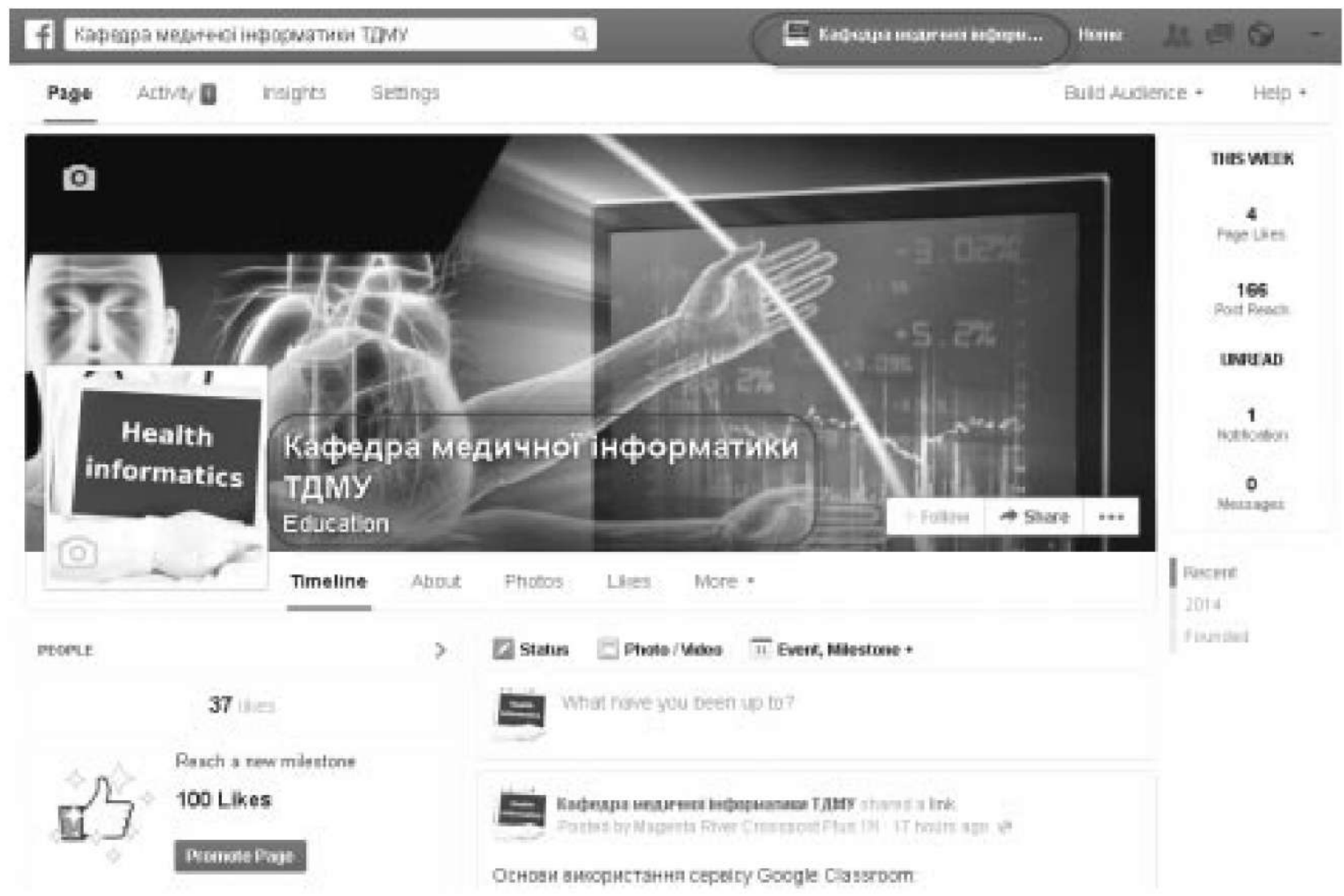

Рис. 12. Сторінка кафедри медичної інформатики ТДМУ в соціальній мережі Facebook.

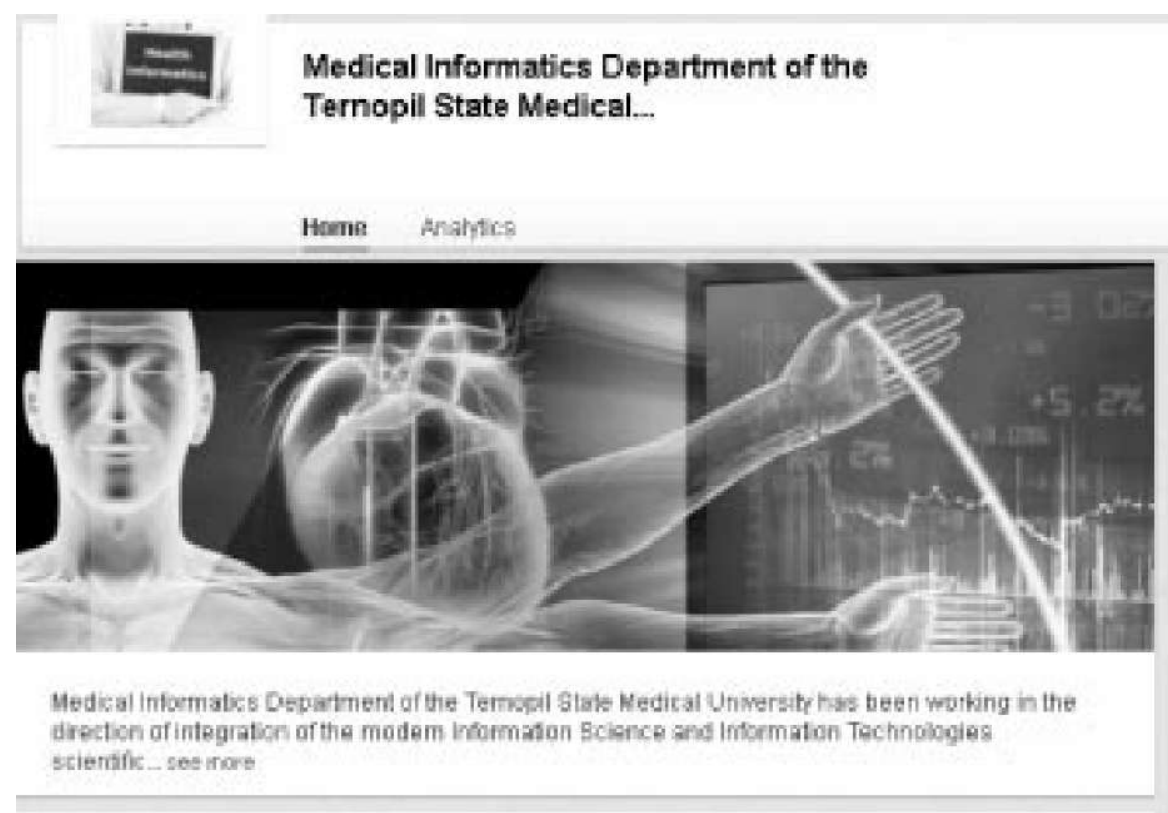

\section{Recent Updates}

Bedical Irformatics Departiment of the Ternopi siate Berical Lnher sity - How I use

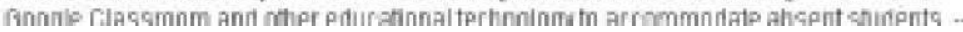

5 follomers

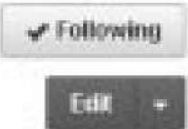

How You're Cannected

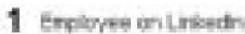

Sed

Рис. 13. Сторінка кафедри медичної інформатики ТДМУ в соціальній мережі Linkedln. 


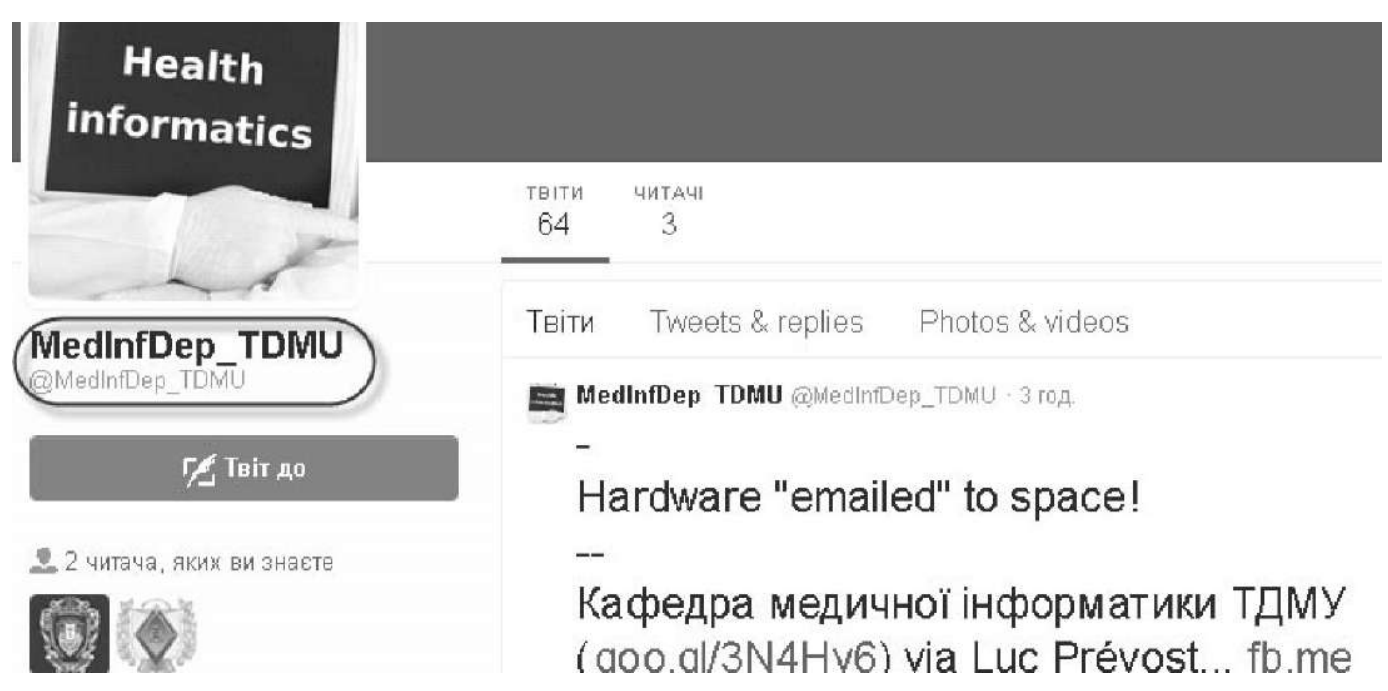

Рис. 14. Сторінка кафедри медичної інформатики ТДМУ в соціальній мережі Twitter.

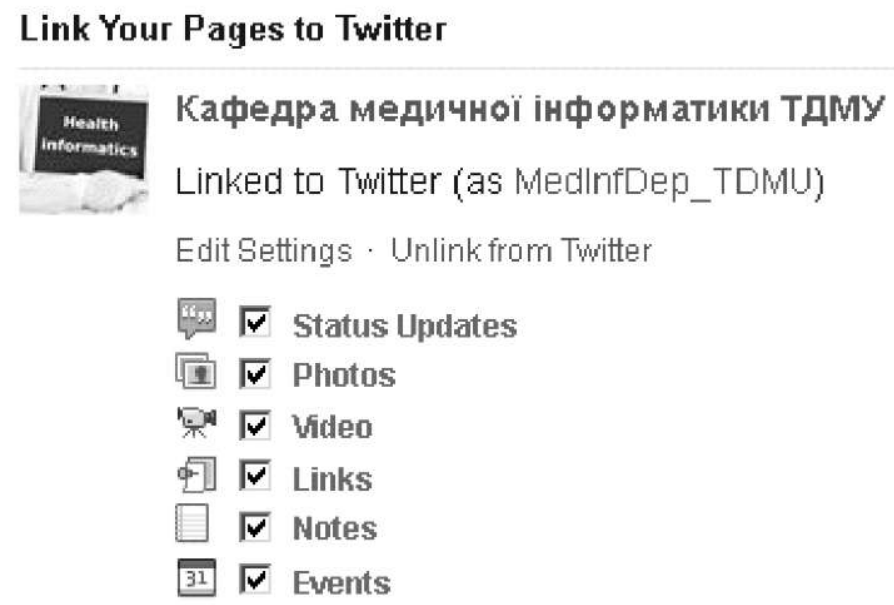

Рис. 15. Налаштування автоматичної публікації сповіщень у соціальній мережі Twitter про оновлення інформації на сторінці кафедри медичної інформатики ТДМУ в соціальній мережі Facebook.

повідомлень 3 Google + в одночасно соціальних мережах FacebookтaLinkedIn (рис. 16). Типовий алгоритм використання даного сервісу менеджером для автоматизації розміщення повідомлень у соціальних мережах такий:

1. Реєстрація облікового запису на сервері Magenta River. Можливо використати дані персонального облікового запису Google для входу.

2. Добавлення необхідних сторінок (1 на рис. 16) як джерела інформації (Google Plus Source).

3. Формування профілів для автоматичного розміщення повідомлень. Для кожного профілю вказується джерело повідомлень (сторінкаGoogle +)тацільовасторінка в тій чи іншій соціальній мережі (2, Знарис. 16).

Результатом виконання вищевказаних алгоритмів стало формування набору сторінок, що зараз утво- рюють інформаційне представництво кафедри медичної інформатики ТДМУ в таких соціальних мережах:

- GOOGLE + - https://plus.google.com/ 105928281998211737833/;

- YouTube - https://www.youtube.com/channel/ UCG65ItT1rtLwBQwff9fb91A;

- Facebook - https://www.facebook.com/TDMU. MedicallnformaticsDepartment;

- Twitter - https://twitter.com/MedInfDep_TDMU ;

- LinkedIn - https://www.linkedin.com/company/ medical-informaics-department-of-the-ternopil-statemedical-university.

Загальна схема організації автоматизованого інформаційного представництва кафедри медичної інформатики ТДМУ в соціальних мережах показана на рисунку 17. 


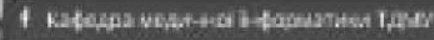

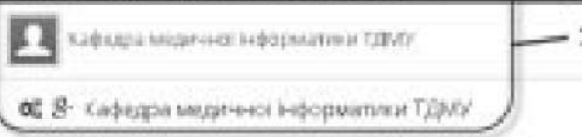

Рис. 16. Налаштування сервісу Magenta River для автоматизації репосту повідомлень з сторінки кафедри медичної інформатики ТДМУ в соціальній мережі Google + в одночасно соціальних мережах Facebook ta Linkedln.

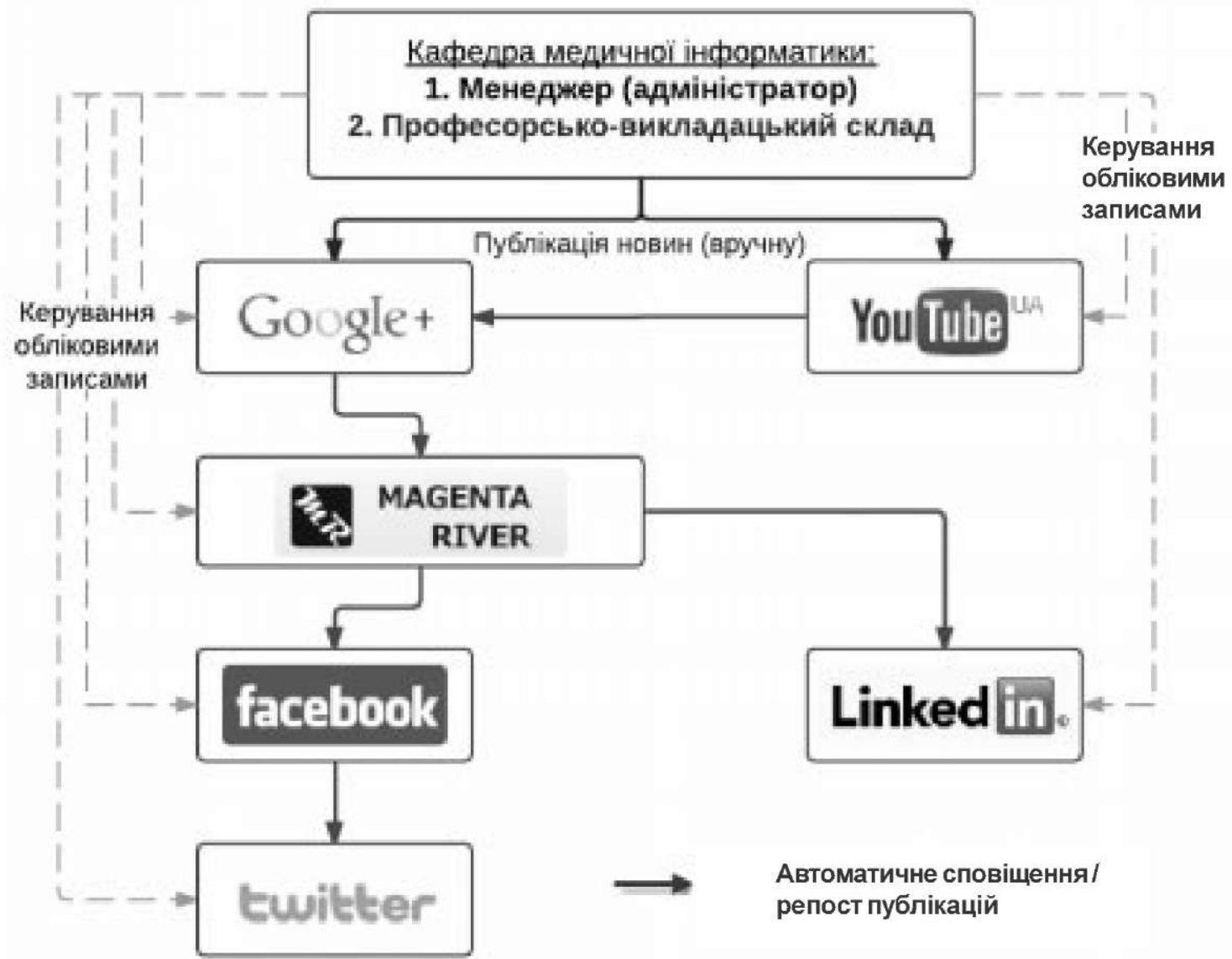

Рис. 17. Автоматизоване інформаційне представництво кафедри медичної інформатики ТДМУ в соціальних мережах. 
3.2. Статистика використання можливостей соичіальних мереж на кафедрі медичної інформатики ТДМУ

Станом на кінець грудня 2014 р. авторами зібрано статистичні дані щодо використання потенціалу соціальних мереж на кафедрі медичної інформатики ТДМУ (табл. 2, рис. 18, 19). Аналіз вказаних даних показує такі основні напрямки використання соціальних мереж на кафедрі медичної інформатики:

- ознайомлення аудиторії користувачів з новинкамив галузі інформаційних технологій та їх застосуванням у галузі охорони здоров'я та медичної освіти;

- публікація посилань на цікаві навчальні та наукові онлайнові ресурси, статистичні банки даних і т. п.;

- представлення інформації про науково-дослідну та навчально-методичну роботу викладачів кафедри.

Щодо недоліків використання існуючих сторінок кафедри медичної інформатики ТДМУ в соціальних мережах, то автори відзначають такі найбільш суттєві:
- не відображається планування майбутніх заходів;

- низька активність використання сервісу YouTube (наявні лише підписки на новини інших каналів);

- слабке використання можливостей соціальної мережі професійних контактів Linkedln.

Слід зазначити, що вказані статистичні дані (табл. 2) стосуються періоду 1 місяць (за винятком Google + - 50 днів). Звідси очевидним є висновок про вищу ефективність інформаційної кампанії, що ії проводить кафедра медичної інформатики ТДМУ в соціальних мережах, порівняно з інформаційною діяльністю пресслужби ТДМУ. До цього варто додати, що ряд найбільш рейтингових повідомлень на сторінках ТДМУ в соціальних мережах було зроблено А. В. Семенцем як відповідальним адміністратором. Окремий інтерес становить порівняння активності використання соціальних мереж різними медичними ВНЗ, на прикладі використання вбудованих засобів аналізу соціальної мережі Facebook (рис. 20).

Таблиця 2. Зведені дані щодо використання соціальних мереж на кафедрі медичної інформатики ТДМУ

\begin{tabular}{|l|c|c|c|}
\hline \multicolumn{1}{|c|}{ Назва соціальної мережі } & Повідомлень & Переглядів & Підписників \\
\hline Google + & 64 & 9,6 тис. & 26 \\
\hline Facebook & 72 & 1,2 тис. & 38 \\
\hline Twitter & 70 & - & 3 \\
\hline YouTube & - & - & 1 \\
\hline Linkedln & 25 & 54 & 5 \\
\hline
\end{tabular}

Views 19 9,861 All-time total

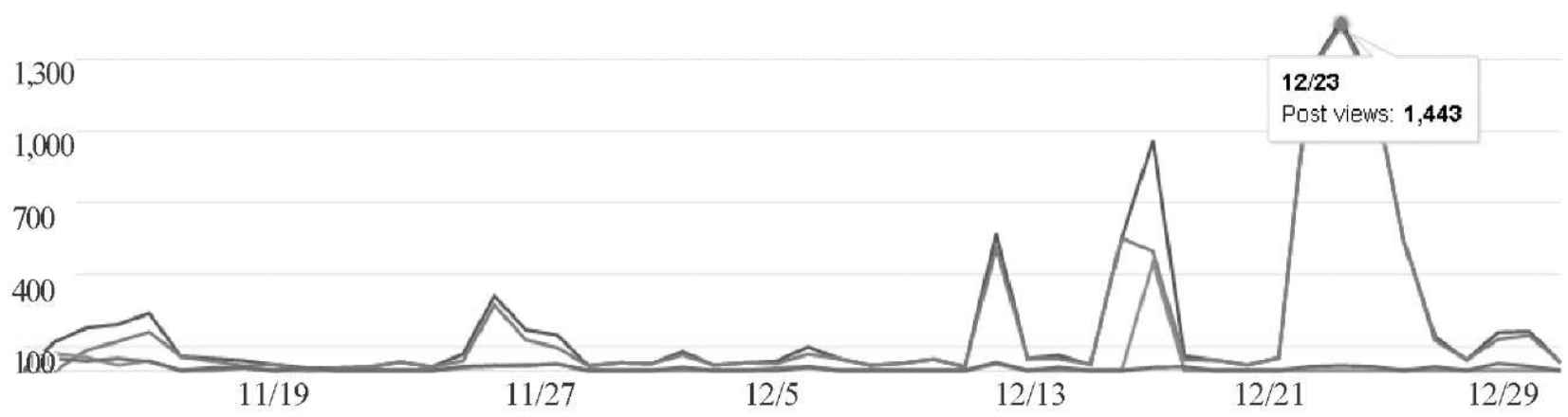

Рис. 18. Діаграма відвідуваності сторінки кафедри медичної інформатики ТДМУ в соціальній мережі Google + протягом листопаду — грудня 2014 року (з моменту створення). 
Page and Tab Visits

The number of times each of your Page tabs was viewed.

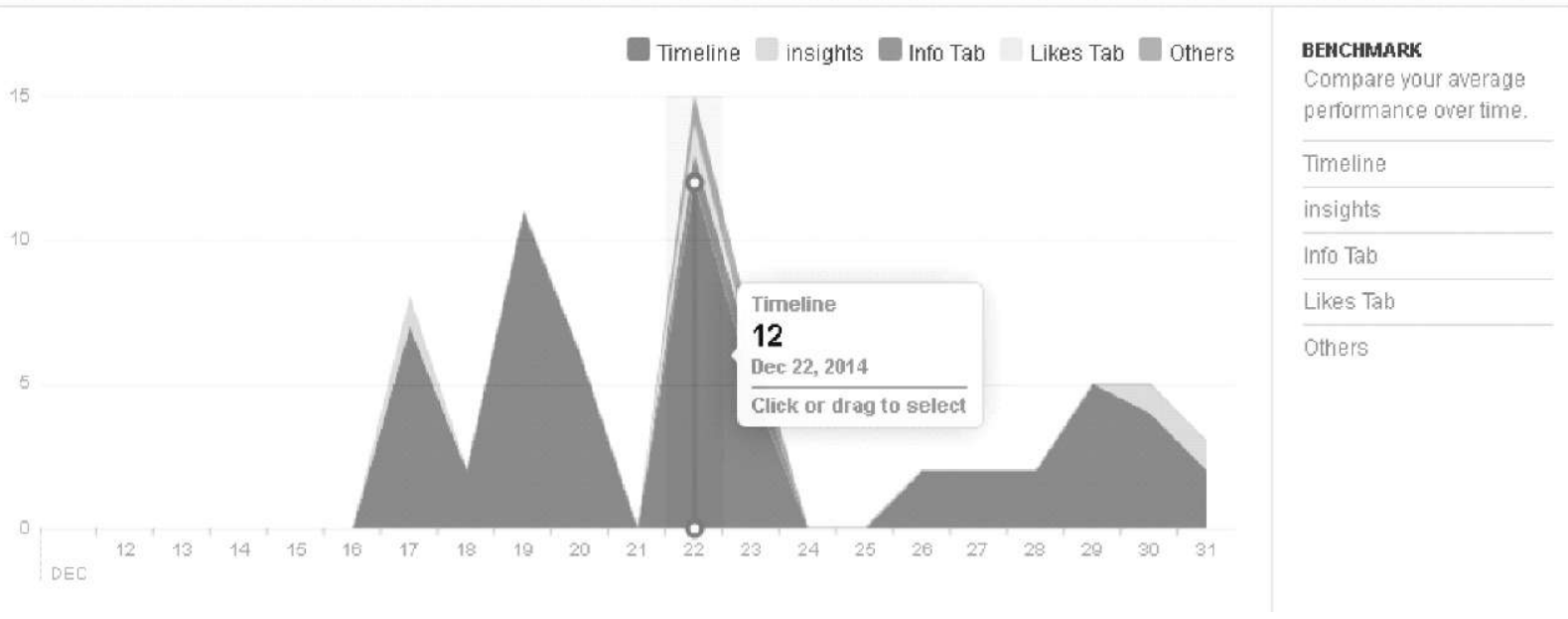

Рис. 19. Діаграма відвідуваності сторінки кафедри медичної інформатики ТДМУ в соціальній мережі Facebook протягом грудня 2014 року (з моменту створення).

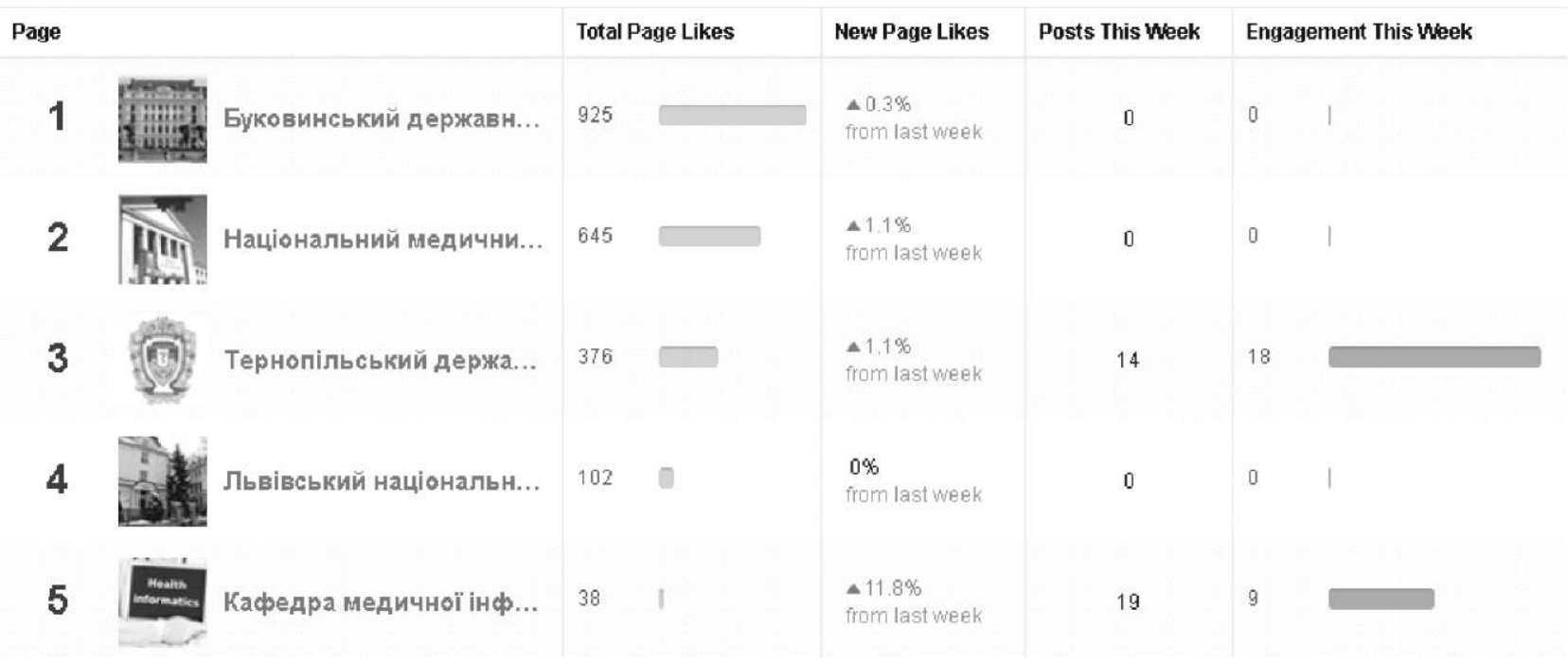

Рис. 20. Порівняння активності використання соціальної мережі Facebook окремими медичними ВНЗ та кафедрою медичної інформатики ТДМУ.

Висновки. В сучасному суспільстві соціальні мережі є засобом розвитку та функціонування його комунікаційних механізмів, чинником становлення нової культури інформаційних обмінів. Таким чином, високої актуальності набуває задача організація інформаційного представництва в соціальних мережах як медичного ВНЗ в цілому, так і його окремих підрозділів. Адаптовані до віртуального інформаційного простору користувачі офіційного сайту вузу є потенційними учасниками спільноти корпоративної соціально-освітньої мережі. Зауважимо, що офіційний сайт вузу не має у своєму розпорядженні таких розвинених інструментів внутрішньої комунікацій, як соціальні мережі.

В роботі авторами показано приклад успішного формування інформаційного представництва в соціальних мережах окремого підрозділу медичного ВНЗ на прикладі кафедри медичної інформатики ТДМУ:

1. Описано основні етапи створення сторінок організації в соціальних мережах.

2. Розроблено методику автоматизації розміщення публікацій з метою зменшення трудомісткості цього процесу та затрат часу викладачами. 
3. Проаналізовано інформаційну ефективність застосування соціальних мереж у галузі вищої медичної (фармацевтичної) освіти.

Серед основних проблем при впровадженні соціальних мереж в організацію освітнього процесу та наукових досліджень слід назвати:

- складнощі залучення учасників в мережу, стимулювання спілкування, створення атмосфери довіри;

\section{Список літератури}

1. Бабин Н. Е. Социальные сети как веб-сервис в организации образовательного процесса в вузе / Е. Н. Бабин, Н. В. Редько//МатериалыУ Международной научно-практической конференции "Информационная среда вуза XXI века" (Петрозаводск, 26-30 сент.2011 г.).-Петрозаводск, 2011.-С. 20-24.

2. Соціальні мережі як чинник розвитку громадянського суспільства: [монографія]/ [О. С. Онищенко, В. М. Горовий, В. І. Попик та ін.]; НАН України, Нац. б-ка України ім. В. І. Вернадського.-К., 2013.-220 с.

3. Семенець А. В. Організаційно-методичні підходи впровадження EMR-систем в охороні здоров'я України / А. В. Семенець // Медична інформатика та інженерія. 2013.-№ 3.-C. 35-43.

4. Семенець А. В. Впровадження інформаційно-комунікаційних технологій - необхідна умова ефективної розробки та супроводження сучасних програмних продуктів / А. В. Семенець // Кредитно-модульна система організації навчального процесу у вищих медичних (фармацевтичних) навчальних закладах України на новому етапі: матеріали $\mathrm{X}$ ювілейної Всеукр. навч.-наук. конф. 3 міжнар. участю (Тернопіль, 18-19 квіт. 2013 р.): у 2 ч. / Терноп. держ. мед. ун-т ім. І. Я. Горбачевського. - Тернопіль : ТДМУ, 2013. Ч.1.-С. 455-463.

5. Дмитренко О. Аудиторія українського інтернету сповільнила свій ріст - за рік зросла лише на $12 \%$ [Електроннийресурс]/О. Дмитренко.-Режим доступу до документа: http://watcher.com.ua/2014/08/19/audytoriya-ukrayinskohointernetu-spovilnyla-sviy-rist-za-rik-zrosla-lyshe-na-12/

6. Огляд соціальних мереж і Твіттера в Україні. Заданими Пошуку у блогах Яндекса (http://blogs.yandex.ua), 20132014 роки [Електронний ресурс]. - Режим доступу до документа : http://download.yandex.ru/company/ Yandex_on_UkrainianSMM_Summer_2014.pdf
- стимулювання у студентів, аспірантів, магістрантів бажання ділитися, обмінюватися знаннями;

- мотивацію викладачів і часто невисокий рівень їх ІКТ-компетенцій;

- відсутність методики управління віртуальним колективом учасників соціально-освітньої мережі, моделей їх взаємодії.

7. Top 7 Social Media Sites in Ukraine from Nov 2013 to Nov 2014 I StatCounter Global Stats/ [Електронний ресурс]. Режим доступу до документа : http: //gs.statcounter.com/ \#all-socialmedia-UA-monthly-201311-201411

8. Biancani S. Social Networks Research in Higher Education/ S. Biancani, D.A. McFarland//Higher Education: Handbook ofTheory and Research: [M.B.Paulsen(ed.)].-2013.-Vol. 28, Ch.4.-P. 151-152,175-184.

9. Frank Rennie. E-Learning and Social Networking Handbook: Resources for Higher Education $2^{\text {nd }}$ ed. / Frank Rennie,TaraMorrison.-NY : Routledge, 2013.-199 p.

10. Семенець А. В. Застосування хмарних технологій при побудові інформаційної інфраструктури медичного ВНЗ / А. В. Семенець // Медична освіта. - 2014. - № 1. C. 99-104.

11. ChristinaAllen. Introducing LinkedIn University Pages / ChristinaAllen [Електроннийресурс]. -Режим доступу до документа: http://blog.linkedin.com/2013/08/19/introducinglinkedin-university-pages/

12. Adding a Company Page | LinkedIn Help Center [Електронний ресурс]. - Режим доступу до документа : https://help.linkedin.com/app/answers/detail/a_id/710/-/ adding-a-company-page.

13. Publishing to Twitter from Facebook Pages [Електронний ресурс]. - Режим доступу до документа : https://www.facebook.com/notes/facebook/publishing-totwitter-from-facebook-pages/123006872130.

14. How to Post on Facebook via Google + [Електронний pecypc]. - Режим доступу до документа :http:// www.wikihow.com/Post-on-Facebook-via-Google $\% 2 \mathrm{Btf}$ Posting_on_Both_Networks_without_a_Third_Service_sub

Отримано 30.01.15 